\title{
PENINGKATAN KEMAMPUAN PRA-MEMBACA KATA PADA ANAK KELOMPOK B TK PUSIDE MUSI MELALUI MEDIA PERMAINAN KARTU HURUF
}

\author{
Oleh: \\ Amalia Nur Fitriya \\ cime1549@gmail.com \\ TK Puside Musi Talaud
}

\begin{abstract}
Abstrak
Penelitian ini bertujuan untuk mengetahui hasil kemampuan pra-membaca dengan menggunakan media permainan kartu huruf pada anak kelompok B di TK Puside Musi Talaud. Tujuan kedua penelitian ini adalah untuk mengetahui ada tidaknya pengaruh kemampuan pra-membaca dengan menggunakan media permainan kartu huruf pada anak kelompok B di TK Puside Musi Talaud. Penelitian ini menggunakan pendekatan kuantitatif. Populasi penelitian adalah siswa kelompok B TK Puside Musi Talaud dengan jumlah 16 orang siswa. Berdasarkan analisis data dapat disimpulkan bahwa ada pengaruh yang signifikan terhadap penggunaan kemampuan pra-membaca pada anak kelompok B di TK Puside Musi Talaud menggunakan media permainan kartu huruf. Hasil penelitian ini dalam pembelajaran pra-membaca atau membaca permulaan pada anak kelompok B peranan media sangat penting mengingat anak-anak masih amat senang bermain sambil belajar. Berdasarkan pengamatan awal di di TK Puside Musi Talaud bahwa dalam proses pra-membaca, selama ini (1) anak kurang antusias dalam mengikuti pelajaran, (2) pengenalan huruf pada anak-anak sangat terbatas, (3) guru hanya menggunakan metode ceramah. Berdasarkan hasil penelitian ini, guru menerapkan kegiatan pembelajaran pra-membaca yang menyenangkan dan inovatif dengan kartu huruf. Dengan demikian anak usia din lebih mudah mengenal huruf untuk meningkatkan kemampuan pra-membaca.
\end{abstract}

Kata Kunci: kemampuan pra-membaca, anak kelompok B, permainan kartu huruf

\begin{abstract}
The aim of the research is to identify the students' pre-reading skill using alphabet game card media to the kindergarten students in TK Puside Musi Talaud group B. The second aim is to discover whether or not there is influence on the students' pre-reading skill after treatment using alphabet game card to the students of TK Puside Musi Talaud group B. Quantitative approach is used in the research. Population of the research is 16 students of TK Puside Musi Talaud group B. Based on the data analysis, it can be concluded that there is a significant influence to the students' pre-reading skill after the use of alphabet game card media. The research result showed that the media plays an important role in the pre-reading learning or the early reading to the students of group B with the fact that children are happy to play when they learn. The initial observation in TK Puside Musi Talaud revealed that so far in the pre-reading process (1) students were less enthusiastic in following the lesson, (2) the alphabet introduction to the students were so inadequate, (3) teachers only employed the lecturing method. Based on the research result, teachers can create interesting and innovative learning activities in pre-reading lesson through the use of alphabet card. Therefore it will be easier for early-aged students to get to know alphabet to improve their pre-reading skill.
\end{abstract}

Keywords: pre-reading skill, group B students, alphabet card game 


\section{Pendahuluan}

Membaca pada hakikatnya adalah suatu kegiatan rumit yang melibatkan banyak hal, tidak hanya sekedar melafalkan tulisan, tetapi juga melibatkan aktivitas visual, berpikir, psikolinguistik, dan metakognitif (Crawley dan Mountain dalam F. Rahim, 1995 : 2). Membaca adalah sekedar menyuarakan lambinglambang tertulis tanpa mempersoalkan apakah kalimat atau kata-kata yang dilisankan tersebut di pahami atau tidak.

Pembelajaran membaca permulaan merupakan pembelajaran membaca tahap awal dan menjadi dasar pembelajaran membaca lanjut yang dilaksanakan di kelas-kelas tinggi. Membaca permulaan diberikan melalui dua tahap, yakni pramembaca dan membaca. Pada tahap pramembaca, kepada siswa di ajarkan dengan cara mengenalkan huruf alphabet a-z, dan kemudian menggabungkan menjadi suku kata agar mempermudah anak dalam memulai membaca. Sedangkan pada tahap membaca permulaan, anak diajarkan untuk membaca suku kata menjadi sebuah kata, dan mengenalkan anak mengenai huruf mati (paten). Sehingga mempermudah anak untuk membaca beberapa kata menjadi sebuah kalimat.

Sebagai kemampuan yang mendasari anak pada kemampuan berikutnya, maka kemampuan membaca permulaan benar-benar memerlukan perhatian guru. Sebab jika dasar itu tidak kuat, maka pada tahap membaca lanjut siswa akan mengalami kesulitan untuk dapat memiliki kemampuan membaca seperti yang di harapkan oleh guru. Menurut Tampubolon (1990 : 5) membaca adalah suatu cara untuk membina daya nalar. Dengan terbiasa membaca daya nalar maka siswa akan menjadi lebih terbina.

Dalam hal ini berdasarkan hasil observasi selama berada di TK PUSIDE MUSI TALAUD diperoleh data pada saat proses pembelajaran membaca permulaan atau pra-membaca ditinjau dari aspek aktivitas kegiatan belajar anak kelompok B TK PUSIDE MUSI TALAUD, yaitu dalam hal belajar mengenal huruf untuk kegiatan pra-membaca anak-anak dapat di kategorikan belum mampu untuk kegiatan pra-membaca. Mereka belum mengenal huruf alphabet a-z yang di gunakan sebagai dasar untuk kegiatan belajar membaca permulaan. Sedangkan aktivitas guru pada saat menjelaskan materi dengan menggunakan metode ceramah pada anakanak yang hanya mendengarkan penjelasan guru tidak berjalan dengan optimal. Selain itu guru juga meminta anak untuk menghubungkan gambar sesuai dengan simbol yang melambangkannya sebagai sarana kegiatan belajar membaca tetapi anak-anak dalam mengerjakan masih ada yang salah karena mereka belum mengerti dan kemudian guru bertanya pada anakanak tentang materi yang belum di mengerti tetapi anak-anak tidak menjawab.

Berdasarkan identifikasi masalah diatas bahwa kemampuan pra-membaca anak kelompok B masih rendah dan masih belum sesuai dengan standar yang ada di kurikulum 2004. Hal ini di terlihat ketika anak-anak diperlihatkan huruf-huruf alphabet, anak-anak terlihat bingung dan masih belum mengenal huruf-huruf alphabet tersebut. Guru tidak menjelaskan tujuan pembelajaran yang dicapai secara optimal dan hanya menggunakan metode ceramah, sehingga pelajaran terlihat begitu membosankan dan anak-anak tidak tertarik untuk mengikuti pembelajaran pramembaca tersebut.

Dari permasalahan yang di gambarkan diatas maka perlu dicari dan di terapkan metode pembelajaran yang dapat menyenangkan bagi anak sehingga anak dapat aktif dan antusias mengikuti kegiatan belajar pra-membaca.untuk itu di upayakan sebuah alternatif penyelesaian masalah, yaitu dengan menerapkan metode permainan kartu huruf. Dalam pembelajaran pra-membaca guru dapat menggunakan strategi bermain dengan memanfaatkan kartu-kartu huruf melalui 
permainan sederhana sehingga menjadi kegiatan pembelajaran pra-membaca yang menyenangkan bagi anak-anak dan juga guru.

Berdasarkan latar belakang yang telah dipaparkan dalam upaya meningkatkan kemampuan pra-membaca anak, maka diperlukan perbaikan proses dan hasil pembelajarannya dengan harapan akan mengalami peningkatan dan perubahan kearah yang lebih baik. Sehubungan dengan hal tersebut guru bantu sm3t tertarik untuk melakukan penilitian tentang bagaimana meningkatkan kemampuan pra-membaca anak melalui permainan kartu huruf.

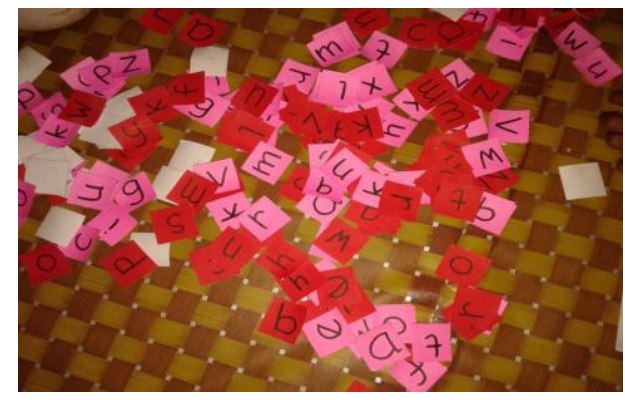

Gambar 1. kartu huruf

\section{Strategi Dari Permasalahan Pra- Membaca}

$\begin{array}{ccc}\text { Salah } & \text { satu } & \text { perkembangan } \\ \text { menyatakan } & \text { bahwa } & \text { perkembangan }\end{array}$ merupakan hasil proses kematangan dan belajar.proses kematangan adalah proses terbentuknya karakteristik yang secara potensial ada pada individu yang berasal dari warisan genetik. Awal masa kanakkanak dapat dianggap sebagai masa belajar (Hurlock, 1980:111). Kematangan usia seorang anak menentukan siap atau tidaknya seorang anak untuk belajar. Perkembangan sangat berperan menentukan waktu yang tepat hingga anak dinyatakan siap untuk belajar membaca.

Anak yang berada pada masa peka untuk belajar membaca akan dengan mudah menerima dan menanggapi rangsangan yang diberikan pada anak dalam bentuk huruf, suku kata, kata, ataupun kalimat. Anak pun akan cepat memberikan respon tiap kali stimulus yang sama muncul, dan sebagai hasilnya anak akan menunjukkan perubahan perilakusebagai indikator keberhasilan proses belajarnya. Yang dalam hal ini berarti anak menguasai kemampuan yang diperlukan dalam membaca.

Kemampuan

pra-membaca merupakan kemampuan awal yang harus dimiliki anak untuk dapat membuka cakrawala pengetahuan yang lebih luas. Salah satu kemampuan yang penting dan harus dikuasai oleh anak-anak adalah kemampuan membaca. Membaca merupakan serangkaian kegiatan pikiran yang dilakukan dengan penuh perhatian untuk memahami suatu informasi melalui suatu indera penglihatan dalam bentuk simbol-simbol yang rumit dan di susun sedemikian rupa sehingga mempunyai arti dan makna. Membaca bukan hanya sedekar membaca, tetapi aktivitas ini mempunyai tujuan untuk mendapatkan sejumlah informasi baru.

Beberapa manfaat dari membaca adalah dapat mengisi waktu luang, mengetahui hal-hal yang actual dan terjadi dilingkungan sekitar, memuaskan pribadi yang membaca, memenuhi tuntutan praktis pribadi yang bersangkutan,meningkatkan pengembangan diri, memuaskan tuntutan intelektual dan spiritual. Terdapat dua aspek yang sangat penting dalam kegiatan pra-membaca, yaitu keterampilan yang bersifat mekanis dan keterampilan yang bersifat pemahaman. Keterampilan mekanis berupa keterampilan memahami huruf, pengenalan unsur-unsur linguistik, dan pengenalaan pola ejaan serta bunyi. Sedangkan keterampilan yang bersifat pemahaman, yaitu keterampilan memahami pengertian sederhana, memahami makna, penilaian, dan kecepatan membaca fleksibel.

Untuk mencapai tujuan yang terkandung dalam keterampilan mekanis, aktifitas yang sesuai adalah membaca nyaring. Pada anak usia dini kemampuan yang harus dipahami anak adalah stimulasi penguasaan kode alphabetic yang 
diajarkan sejak awal di mulainya tahun pertama pembelajaran.

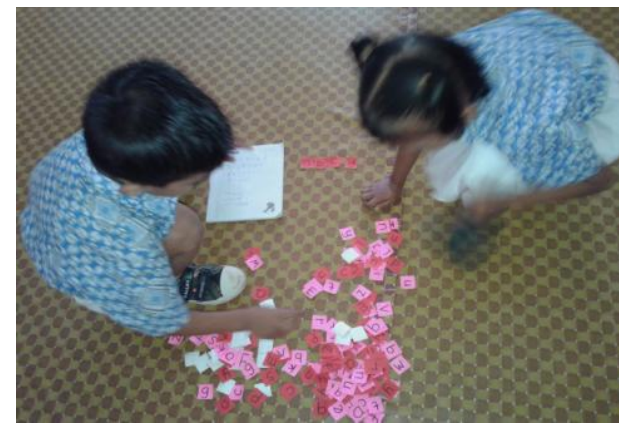

Gambar 2.

Anak-anak sedang mencari huruf yang cocok sesuai perintah

\section{Solusi Dari Permasalahan Pra- Membaca}

Media adalah alat bantu pengajaran dalam kegiatan belajar mengajar yang digunakan untuk menyampaikan pesan atau informasi (Djamarah Syaiful . Wahana dari sumber pesan yang ingin diteruskan kepada penerima pesan dalam menyampaikan materi guna mencapai tujuan pembelajarannya. Perkembangan media pendidikan pada mulanya hanya dianggap sebagai alat bantu mengajar guru untuk mempertinggi minat belajar anak didik dan masih banyak guru saat ini yang juga menganggap bahwa peran media dalam proses pembelajaran terbatas sebagai alat bantu proses pembelajaran.

Tetapi sebagai guru yang professional harus memiliki pandangan sebaliknya, yaitu bahwa media merupakan bagian integral dari keseluruhan proses belajar mengajar. Media pembelajaran tidak berdiri sendiri tetapi saling berhubungan dengan komponen lainnya dalam rangka menciptakan kegiatan belajar mengajar sesuai kondisi yang di harapkan. Hal-hal yang menyebabkan media pembelajaran dapat mempertinggi antusias anak didik dalam kegiatan belajar adalah metode belajar yang lebih aktif dan menarik bagi anak didik dan makna pelajaran dalam proses pembelajaran lebih jelas mengena pada anak didik, sehingga minat anak didik dalam belajar menjadi lebih tinggi.

Kartu huruf merupakan media yang termasuk pada jenis media grafis atau dua dimensi, yaitu media yang mempunyai ukuran panjang dan lebar yang berisi huruf-huruf alphabet serta dapat digunakan untuk mengembangkan perbendaharaan kata dalam pelajaran bahasa. Media pembelajaran ini berupa kartu kecil yang berisi huruf alphabet dan dapat meningkatkan kemampuan mengingat untuk melatih anak dalam mengeja dan memperkaya kosa kata.

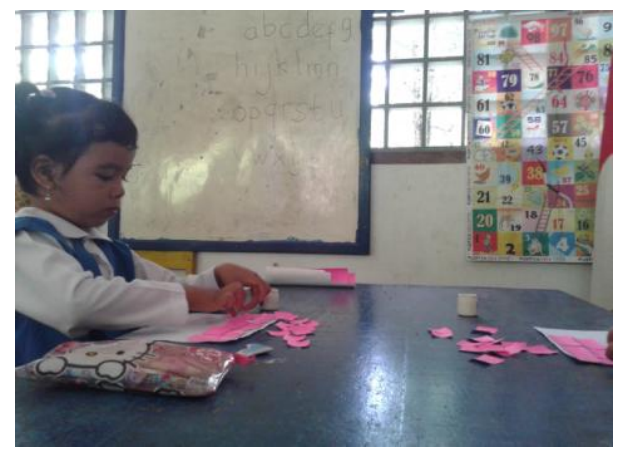

Gambar 3. anak sedang menempel kartu huruf

Persiapan yang matang akan mempermudah kegiatan belajar membaca, sehingga sebelum memulai kegiatan belajar membaca melalui media kartu huruf maka pendidik harus mempersiapkan materi yang akan di berikan dengan cermat dan baik. Materi atau bahan yang perlu dipersiapkan adalah sebagai berikut: 1) membuat kartu yang terbuat dari karton berwarna dengan ukuran $5 \times 50 \mathrm{~cm}$ sebanyak 26 buah, 2) kartu ditulis menggunakan huruf kecil dan disesuaikan dengan tinggi kartu, 3) untuk kegiatan belajar membaca suku kata bisa di lebihkan huruf vokal yang sesuai dengan bahan materi pendidik.

Untuk awal yang baik dapat dimulai dengan olahraga otak ringan untuk mengetahui kemampuan membaca anak dengan cara melihat kartu yang di tunjukkan oleh pendidik. Cara menggunakan kartu huruf dalam pengajaran membaca permulaan Hainstock 
(1999:205) menjelaskan bahwa kartu-kartu huruf yang telah di buat dengan cara membiarkan siswa mengenalkan dirinya sendiri dengan huruf-huruf, memilih huruf dan menggabungkan menjadi suku kata sehingga suku kata tersebut dapat di susun menjadi sebuah kata yang mempunyai arti.

\section{Kesimpulan}

Berdasarkan penelitian yang telah dilaksanakan selama mengabdi di tempat tugas, peneliti dapat mendeskripsikan kesimpulan sebagai berikut:

1. Kondisi awal kemampuan pramembaca anak kelompok B sebelum menggunakan kartu huruf terbilang masih sangat rendah.

2. Perencanaan kegiatan pra-membaca kelompok B dilaksanakan setiap hari untuk menstimulasi kemampuan pramembaca anak melalui kegiatan permainan kartu huruf.

3. Proses kegiatan pembelajaran pramembaca kelompok B setelah menggunakan media permainan kartu huruf yang berlangsung sangat seru, ternyata dapat menarik minat anak untuk belajar mengenal huruf tanpa membosankan. Hal tersebut mengindikasikan bahwa anak-anak begitu fokus terhadap kegiatan pramembaca melalui permainan kartu huruf.

4. Tingkat pencapaian kondisi akhir kemampuan pra membaca anak kelompok B meningkat secara signifikan melalui kegiatan permainan kartu huruf di bandingkan metode ceramah yang di ajarkan guru sebelumnya. Hal ini menunjukkan terdapat pengaruh yang sangat besar pada peningkatan kemampuan pramembaca melalui media permainan kartu huruf.

\section{Daftar Pustaka}

Crawley dan Mountain dalam F. Rahim, 1995 : 2. Pengertian membaca

Tampubolon 1990: 5. Pengertian membaca digilib.ump.ac.id/files/disk1/14/jhptu mp-a-linaindriy-672-2-babii.pdf

https://badryadi.wordpress.com/proposalpenelitian/ketrampilan-membac a/aresearch.upi.edu/operator/upload/s_p aud_1008248_chapter1.pdf

Hainstock www.blogpendidikan.net/2014/01/pe ngertian-media-kartuhuruf.html?m=1 media kartu huruf 